\title{
Perbedaan penerapan model pembelajaran kooperatif SAVI (Somatic, Auditory, Visual, Intellectual) dan model pembelajaran air (auditory, visual, repetition) pembelajaran daring terhadap pemahaman konsep dan kemandirian belajar mata pelajaran kerja bengkel dan gambar teknik kelas x TEI SMKN 2 Pasuruan
}

\author{
Fandi Akhmad Kurniawan, Syaad Pathmantara *, Hari Putranto \\ Universitas Negeri Malang, Jl. Semarang No. 5 Malang, Jawa Timur, Indonesia \\ *Penulis korespondensi, Surel: syaad.ft@um.ac.id
}

Paper received: 03-01-2021; revised: 15-01-2021; accepted: 30-01-2021

\begin{abstract}
Abstrak
Penelitian ini bertujuan untuk mengetahui perbedaan pemahaman konsep dan kemandirian belajar karena pengaruh model pembelajaran SAVI dan model pembelajaran AIR pada mata pelajaran Kerja Bengkel dan Gambar Teknik siswa kelas X TEI SMKN 2 Pasuruan. Jenis penelitian ini adalah quasi experiment dengan model pretest posttest control design. Subjek penelitian ini adalah siswa kelas X Teknik Elektronika Industri SMKN 2 Pasuruan dengan jumlah siswa 72 orang. Uji hipotesis menggunakan Independent Sample T-test dengan taraf signifikan 5\%. Instrumen pengukuran berupa tes kognitif berdasarkan pada indikator pemahaman konsep dan kemandirian belajar. Hasil penelitian dapat dilihat pada beberapa aspek berikut; (1) pemahaman konsep yang diberikan perlakuan model pembelajaran SAVI paham konsep sebesar 80,79\%, miskonsepsi 7,03\% dan tidak paham konsep 12,72\%, (2) pemahaman konsep yang diberikan perlakuan model pembelajaran AIR paham konsep sebesar 62,67\%, miskonsepsi 19,66\% dan tidak paham konsep 14,10\%, (3) Perpaduan model SAVI lebih unggul dalam pengimplementasian pembelajaran untuk membuat siswa lebih aktif paham konsep dan kemandirian belajar dibandingkan model pembelajaran AIR. Kesimpulan dari penelitian ini adalah tingkat pemahaman konsep pada siswa yang diberi perlakuan model pembelajaran SAVI dibandingkan siswa yang diberi perlakuan model pembelajaran AIR memiliki perbedaan yang signifikan. Saran yang dianjurkan dalam penelitian selanjutnya adalah kedua model pembelajaran tersebut dapat digunakan sebagai model alternatif untuk meningkatkan pemahaman konsep dan kemandirian belajar siswa.
\end{abstract}

Kata kunci: model pembelajaran savi; model pembelajaran air; pemahaman konsep; kemandirian belajar.

\section{Pendahuluan}

Pendidikan pada dasarnya adalah usaha sadar untuk menumbuh kembangkan potensi sumber daya manusia peserta didik dengan cara mendorong dan memfasilitasi kegiatan belajar mereka. Pengertian Pendidikan menurut Undang - Undang sistem Pendidikan Nasional No. 20 tahun 2000 adalah usaha sadar dan terencana untuk mewujudkan suasana belajar dan proses pembelajaran agar peserta didik secara aktif mengembangkan potensi dirinya untuk memiliki kekuatan spiritual keagamaan, pengendalian diri, kepribadian, kecerdasan, akhlak mulia, serta keterampilan yang diperlukan dirinya dan masyarakat.

Guru merupakan salah satu bagian penting dalam pembelajaran, oleh karena itu pelatihan bagi para guru sangat perlu untuk mengejar pembangunan kesadaran siswa dan kemampuan untuk mengaplikasikan pengetahuan mereka pada konteks yang lebih kompleks, 
mengintegrasikan pengetahuan dengan sikap pribadi mereka dan nilai-nilai kehidupan, kemudian membangun personalitas mereka dan kemampuan profesional (Blanco, dkk., 2013). Program pelatihan bagi guru juga harus mengadopsi banyak holistik yang ada (kognitif, didatik, teknikal dan afektif), sehingga guru dapat membelajarkan siswanya dengan baik dan guna tercapainya tujuan pembelajaran yang dimaksud.

Penerapan model yang tepat dan sesuai akan memungkinkan untuk menghasilkan proses pembelajaran yang berpusat pada siswa. Dengan proses pembelajaran yanng berpusat pada siswa diharapkan dapat membangun pengetahuannya melalui mengamati, menanya, menalar, mencoba dan mengkomunikasikan sehingga terjadi timbal balik antara guru dan siswa. Kurikulum 2013 merupakan kurikulum baru yang mulai diterapkan pada tahun 2013/2014. Pada kurikulum 2013 ini adalah adanya peningkatan dan keseimbangan soft skill dan hard skill yang meliputi aspek kompetensi sikap, selain itu pembelajaran lebih bersifat tematik integrative dalam semua mata pelajaran (Rahman \& Bahar, 2019).

Pada studi lapangan ditemukan permasalahan terkait dengan penerapan model pembelajaran yang tepat. Hal tersebut dibuktikan dengan penemuan data dimana peneliti pada saat melakukan kegiatan Kajian Praktek Lapangan (KPL) yang dialami saat pembelajaran berlangsung ketika peneliti melakukan observasi di SMK Negeri 1 Kepanjen yaitu pembelajaran kurang efektif guru masih menggunakan Teacher Center di sekolah dan siswa cenderung monoton, sehingga materi yang diajarkan menjadi verbal/hafalan sedangkan siswa lebih banyak berperan sebagai pendengar dan pencatat. Hal tersebut masih belum bersinergi dengan kurikulum 2013 yang medepankan kemandirian peserta didik.

Kondisi tahun 2020 dimana terjadi pandemi/pagebluk yang disebabkan oleh sebaran virus SARS-Cov 2 (Covid-19) menyebabkan guru perlu mengupayakan pembelajaran daring yang tetap berkualitas sehingga peserta didik tetap mampu mengembangkan potensi diri walaupun dilakukan secara daring. Model pembelajaran yang sesuai menjadikan siswa aktif, kreatif dan berlatih kemampuan bekerjasama, kemandirian, yang dilakukan pada pembelajarn daring diantaranya model pembelajaran Somatic, Auditory, Visualization, intellectually (SAVI) dan model pembelajaran Auditory, intellectually, repetition (AIR).

Model pembelajaran Somatic, Auditory, Visualization, intellectually (SAVI) adalah model pembelajaran yang menekankan bahwa belajar haruslah memanfaatkan semua alat indra yang dimiliki peserta didik (Ibrahim, 2015). Dengan memperhatikan konsep belajar SAVI, siswa mempunyai kesempatan untuk berperan aktif dalam proses belajar mengajar (Fitriani, 2019) sehingga dengan menggunakan pendekatan model pembelajaran SAVI diharapkan dapat meningkatkan hasil belajar siswa (Putri, dkk., 2017). Kreativitas pembelajaran akan berlangsung secara optimal jika aktivitas intelektual dan semua alat indra digabungkan dalam suatu kinerja pembelajaran.

Tujuan dari penelitian ini yaitu: 1) mengetahui deskripsi pemahaman konsep dan kemandirian belajar dengan model pembelajaran SAVI; 2) mengetahui deskripsi pemahaman konsep dan kemandirian belajar dengan model pembelajaran AIR; 3) mengetahui perbedaan pemahaman konsep dan kemandirian belajar dengan metode SAVI dan AIR.

Hipotesis yang dapat ditarik dari penelitian ini yaitu: 1) tidak terdapat perbedaan pemahaman konsep dan kemandirian belajar dengan menggunakan model pembelajaran SAVI 
dan AIR; 2) terdapat perbedaan pemahaman konsep dan kemandirian belajar dengan menggunakan model pembelajaran SAVI dan AIR.

\section{Metode}

Penelitian ini menggunakan penelitian eksperimen dengan pendekatan kuantitatif. Penelitian ini menggunakan true experimental design dengan pola pretest-postest. Penelitian ini menggunakan dua kelas, yaitu kelas A dan kelas B. Diantara kedua kelas tersebut samasama diberi perlakukan dengan segi tujuan yang sama, materi, dan metode pembelajaran. Sumber data dari penelitian ini adalah sampel dari total populasi siswa kelas X TEI di SMKN 2 Pasuruan sebanyak 36 sampel. Instrumen penelitian yang digunakan terbagi menjadi dua yaitu Instrumen perlakuan yang meliputi Silabus, Rencana elaksanaan pembelajaran (RPP), dan Bahan ajar; serta Instrumen penilaian yang meliputi kisi-kisi soal, tes tertulis, dan lembar angket. Teknik pengumpulan data pada penelitian ini meliputi: 1) tahap persiapan; 2) tahap pelaksanaan; dan 3)tahap akhir. Teknis analisis data yang digunakan dalam penelitian ini meliputi: 1) Uji Normalitas; 2) Uji Homogenitas; dan 3) Uji Hipotesis.

\section{Hasil dan Pembahasan}

Berikut merupakan sebaran frekuensi nilai postest kelas eksperimen A untuk metode pembelajaran SAVI.

Tabel 1. Distribusi frekuensi nilai posttest kelas eksperimen A (SAVI)

\begin{tabular}{llllll}
\hline Interval Ideal & $\begin{array}{l}\text { Frekuensi } \\
\text { Lapangan }\end{array}$ & Persentase & Kategori & Rata-Rata & Kriteria \\
\hline $85-100$ & 10 & $27,7 \%$ & Sangat Tinggi & & \\
$70-85$ & 10 & $27,7 \%$ & Tinggi & 70,5 & Tinggi \\
$55-70$ & 11 & $30,5 \%$ & Sedang & \\
$40-55$ & 2 & $5,5 \%$ & Rendah & \\
$25-40$ & 3 & $8,3 \%$ & Sangat Rendah & \\
Total & 36 & $100 \%$ & & \\
\hline
\end{tabular}

Berdasarkan tabel 1.0 diketahui bahwa rata-rata nilai posttest siswa eksperimen A dengan menggunakan metode pembelajaran SAVI diasusmsikan pada kretiria tinggi dengan rata-rata sebesar 70.5. Berikut merupakan distribusi frekuensi nilai Posttest siswa eksperimen B dengan menggunakan model pembelajaan.

Tabel 2. Distribusi Frekuensi Nilai Post-test Kelas Eksperimen B (AIR)

\begin{tabular}{llllll}
\hline Interval Ideal & $\begin{array}{l}\text { Frekuensi } \\
\text { Lapangan }\end{array}$ & Persentase & Kategori & Rata-Rata & Kriteria \\
\hline $85-100$ & 5 & $13,8 \%$ & Sangat Tinggi & & \\
$70-85$ & 7 & $19,4 \%$ & Tinggi & 56,1 & Sedang \\
$55-70$ & 8 & $22,2 \%$ & Sedang & \\
$40-55$ & 6 & $16,6 \%$ & Rendah & \\
$25-40$ & 11 & $30,5 \%$ & Sangat Rendah & \\
Total & 36 & $100 \%$ & & \\
\hline
\end{tabular}

Berdasarkan tabel 2.0 diktahui bahwa rata-rata hasil belajar siswa eksperimen B diasumsikan sedang dengan nilai rata-rata sebesar 56.1. Berikut merupakan hasil komparasi aspek pemhaman konsep pasca pemberian perlakuan. 
Jurnal Inovasi Teknik dan Edukasi Teknologi (JITET), 1(1), 2021, 59-63

Tabel 3. Pemahaman Konsep Siswa Setelah diberi Perlakuan

\begin{tabular}{llll}
\hline \multirow{2}{*}{ Kelas } & \multicolumn{3}{l}{ Tingkat Pemahaman } \\
\cline { 2 - 4 } & P (Paham) & M (Miskonsepsi) & TP (Tidak Paham) \\
\hline Kelas A & $80,79 \%$ & $7,03 \%$ & $12,72 \%$ \\
Kelas B & $62,67 \%$ & $19,66 \%$ & $14,10 \%$ \\
\hline
\end{tabular}

Berdasarkan Tabel 3.0 hasil posttest total rata-rata siswa kelas A yang dinyatakan paham konsep sebesar 80,79\%, miskonsepsi 7,03\% dan tidak paham konsep 12,72\%. Sedangkan total rata-rata siswa kelas B dinyatakan paham konsep sebesar 62,67\%, miskonsepsi 19,66\% dan tidak paham konsep 14,10\%. Berdasarkan hasil uji hipotesis dapat diambil keputusan bahwa terdapat perbedaan kemandirian belajar siswa kerja bengkel dan gambar teknik siswa sesudah belajar antara menggunakan model pembelajaran SAVI (Somatic, Auditory, Visual, Intellectual) dan kemandirian belajar siswa kerja bengkel dan gambar teknik siswa menggunakan model pembelajaran AIR (Auditory, Intellectual, Repetition).

nilai rata-rata pemahaman konsep ranah pengetahuan dan kemandirian belajar yang diperoleh kelas A yang menggunakan model pembelajaran SAVI lebih unggul dari kelas B yang menggunakan model pembelajaran AIR. Pemahaman konsep SAVI termasuk ke dalam kriteria tinggi, sedangkan pemahaman konsep AIR termasuk ke dalam kriteria sedang. Dari beberapa uraian diatas, maka dapat disimpulkan bahwa perbedaan pemahaman konsep dan kemandirian belajar yang telah dicapai oleh siswa dengan menggunakan kedua model tersebut penerapan model SAVI lebih unggul dari pada model AIR.

Model pembelajaran SAVI menekankan pada kegiatan mulai dasar dan melibatkan seluruh kemampuan siswa pada pemahaman konsep dan kemandirian belajar sehingga siswa menjadi terlatih. Selain itu model pembelajaran SAVI mampu meningkatkan kemandirian belajar siswa (Sumawardani \& Faif Pasani, 2013), dapat mengembangkan kemampuan siswa (Ekawati, 2019), meningkatkan komunikasi dengan siswa lain (Siregar, 2018), serta meningkatkan aktivitas belajar siswa (Rahayu, dkk., 2019).

\section{Simpulan}

Berdasarkan hasil penelitian dan pemahaman yang telah diuraikan, dapat diambil kesimpulan sebagai berikut. Model pembelajaran SAVI dapat menghasilkan pemahaman konsep dan kemandirian belajar yang tinggi. Model pembelajaran AIR menunjukkan hasil pemahaman konsep dan kemandirian belajar yang sedang. Terdapat signifikansi perbedaan pemahaman konsep dan kemandirian belajar siswa pada mata pelajaran Kerja Bengkel Gambar Teknik, kelas A yang diberikan model pembelajaran SAVI dan kelas B yang diberikan model pembelajaran AIR.

\section{Daftar Rujukan}

Blanco, L. J. Guerrero Barona, E., \& Caballero Carrasco, A. (2013). Cognition and affect in mathematics problem solving with prospective teachers. The Mathematics Enthusiast, 10(1), 335-364.

Ekawati, D. (2018). Pengembangan Model Pembelajaran SAVI (Somatis, Audiotoris, Visual Intelektual) Bermedia Video Pada Pembelajaran Drama Kelas Viii a Smpn 1 Menganti, Gresik Tahun Ajaran 2018/2019. Bapala, 5(2), 1-18.

Fitriani, S. N. (2019). Pembelajaran IPA Dengan Model Pembelajaran Savi (Somatis Auditori Visual Intelektual) Terhadap Prestasi Belajar Siswa Kelas IV MI NW Dames. Bada'a: Jurnal Ilmiah Pendidikan Dasar, 1(2), 108-123. 
Jurnal Inovasi Teknik dan Edukasi Teknologi (JITET), 1(1), 2021, 59-63

Ibrahim, N. (2015). Model Pembelajaran SAVI (Somatic, Auditory, Visualization, Intelectual) Untuk Meningkatkan Kemampuan Membaca Puisi: Sebuah Inovasi Pembelajaran Bahasa Indonesia di SD. Prosiding Seminar Nasional Jurusan PGSD FIP UNP Tahun 2015, 1(1), 1689-1699.

Putri, G. M. Panjaitan, R. L. \& Sujana, A. (2017). Penerapan Model Inkuiri Untuk Meningkatkan Motivasi Dan Hasil Belajar Siswa Pada Materi Gaya Dapat Mempengaruhi Gerak Benda. Jurnal Pena Ilmiah, 2(1), 371380. https://doi.org/10.17509/jpi.v2i1.10672

Rahayu, A. Nuryani, P., \& Riyadi, A. R. (2019). Penerapan Model Pembelajaran Savi Untuk Meningkatkan Aktivitas Belajar Siswa. Jurnal Pendidikan Guru Sekolah Dasar, 4(2), 102-111. https://doi.org/10.17509/jpgsd.v4i2.20489

Rahman, A., \& Bahar, S. (2019). Kesiapan Sekolah dalam Mengimplementasikan Kurikulum 2013 (Studi Kasus di Beberapa SD di Kecamatan Palu Barat dan Palu Timur Kota Palu). Jurnal Inspirasi Pendidikan, 9(2), 110-116. https://doi.org/10.21067/jip.v9i2.3324

Siregar, D. S. (2018). Pengaruh Model Pembelajaran SAVI Terhadap Kemampuan Komunikasi Matematis Siswa SMP Negeri 41 Palembang. Jurnal Mathedu, 1(3), 493-497.

Sumawardani, W. \& Faif Pasani, C. (2013). Efektivitas Model Pembelajaran SAVI dalam Pembelajaran Matematika untuk Mengembangkan Karakter Mandiri Siswa. EDU-MAT: Jurnal Pendidikan Matematika, 1(1), 82-89. https://doi.org/10.20527/edumat.v1i1.576. 